\section{University Politics}

SIR,- - I read with considerable interest the article in Nature of October $24(228,314 ; 1970)$ on University Politics and I would like to correct ono statement. This is to the effect that "At both Universities (Cape Town and Witwatersrand) members of staff and students alike . . . talk of thoir Universities as liberal, but it may be significant that this attitude is not usually accompanied by a willingness to embrace modern causes such as student representation". "The fact is that at Witwatersrand, student representation is a very live issue and a great deal has already been achieved in bringing it about. Furthermore, the relationship between the Students' Representative Council and the University Administration is extremely cordial and strong.

\section{Yours faithfully,}

G. R. BozzoLI

Vice-Chancellor and Principal,

University of the Witwatersrand,

Johannesburg.

\section{Obituary}

\section{Professor T. K. Walker}

Thomas Kennedy WaLker, professor of industrial biochemistry at the University of Manchester from 1954 when the chair was established, until his retirement in 1959, died on June 29, 1970, at the age of seventy-seven. Shortly after his death a most stimulating and remarkablo account of the development of his department writien by himself, appeared in Advances in Applied Microbiology $(12,1 ; 1970)$. It describes his very extensive research work, his most happy relations with his studonts and his contacts with numcrous biochemists at home, and especially abroad, and gives a strong impression of a man happy in his work and surroundings, with a growing, but quiet, satisfaction in the progress and reputation of his department. Walker's comments on the mental outlook required by those who would journey from the domain of organic chemistry to that of biochemistry should be read by all who have followed, or would follow, the same path. An article of his on the pollution of the environment will appear shortly.

After graduating at Manchester in 1915, Walker joined Weizmann's group to work on the technical production of acetone and $n$-butanol by an organism related to Fernbach's bacillus. This entailed a period of study at the Lister Institute. His life-long devotion to microbiology arose from this early work. His interest in largescale operations was also enhanced by two years spent at tho Royal Arsenal, Woolwich. These were followed by three years' research with Lapworth at Manchester on the interaction of diazonium salts with reactive methylene groups. From 1922 to 1925, he collaborated with Pyman at tho Manchester College of Technology in an examina tion of the bitter bacteriostatic substance in the resin of hop-cones. Extensions of this work continued at intervals until 1958.

In 1925 Walker began a study of the behaviour of carbohydrates and aliphatic acids in cultures of Aspergillus niger and Aspergillus oryzae, during which acetic, pyruvic, dimothylpyruvic and $\alpha$-ketoglutaric acids were detected in cultures of $A$. niger on various substrates, and the effect of fluoride, iodoacetate and cyanido was examined. Ho was frequently consulted about bacterial infections in yeast and beer and so arose a long serics of investigations, many of considerable importance, on Candida, Acetobacter and Lactobacillus species. $\mathrm{He}$ became a recognized authority on Acetobacter, some species of which were shown to produce cellulose. From 1948 to 1958 he directed, for the Medical Research Council, extensive work on the production of edible fat by mould fungi, in which the cultural conditions for the most suitable moulds and the composition of the fat were closely studied.

Walker's manner was always quiet, friendly and unruffled. His sympathetic and encouraging altitude to the problems of young rescarch students caused him to spend much tirne at their benches. He thus imparted that "fecl" for the contents of a test tube or of an unpromising mixture which is the secret of successful laboratory manipulation and is still the distinguishing mark of the organic chemist. $\mathrm{He}$ had many diverse interests, including poetry and philosophy, and a religious faith that deepened with the lapse of years.

\title{
Announcements
}

\section{University News}

Professor Frank Press has been appointed Robert R. Shrock professor of earth and planetary sciences at the Massachusetts Institute of Technology.

Dr L. Mirsky has been appointed to a personal chair in the Department of Pure Mathematics, University of Sheffield, and the title of visiting professor in botany has been conferred on Professor R. F. Jones, State University of New York at Stony Brook, for the period January 1 to August 31, 1971.

\section{Appointments}

Professor Zdzislaw L. Wilhelmi, head of the Department of Nuclear Physics in the University of Warsaw, has boen appointed director of the Division of Health, Safety and Waste Management in the Department of
Technical Opcrations, International Atomic Energy Agency.

Miss Julia Henderson, associate commissioner for technical cooperation in the United Nations, has been appointed secretary-general of the International Planned Parenthood Federation, in succession to the late Sir David Owen.

\section{International Meetings}

February 18, 1971, Safety in Chemical Manufacturing, London (Institution of Chemical Engineers, 16 Belgrave Square, London SW1).

March 3-5, 1971, Environment and Cancer, Houston (Mrs Jane Brandenburger, M. D. Anderson Hospital and Tumor Institute, Texas Medical Center, Houston, Texas $77025, \mathrm{US} \Lambda$ ). 